\title{
Contrasting Two Clients in Emotion-Focused Therapy for Depression 2: The Case of "Eloise," "It's Like Opening the Windows and Letting the Fresh Air Come In"
}

\author{
RHONDA N. GOLDMAN ${ }^{\mathrm{a}, \mathrm{d}}$, JEANNE C. WATSON ${ }^{\mathrm{b}}$, \& LESLIE S. GREENBERG $^{\mathrm{c}}$ \\ a Illinois School of Professional Psychology at Argosy University, Schaumburg \\ ${ }^{\mathrm{a}}$ University of Toronto \\ ${ }^{\mathrm{c}}$ York University University of Toronto \\ d Correspondence concerning this article should be addressed to Rhonda Goldman, Argosy University, Schaumburg, \\ 999 Plaza Drive, Ste. 100, Schaumburg, IL 60173 \\ Email: rhonda.goldman@comcast.net
}

\begin{abstract}
This paper presents a good-outcome case of "Eloise," an individual drawn from the York II Depression study and treated with emotion-focused therapy (EFT) (Goldman, Greenberg, \& Angus, 2006). Using the case comparison method, this study considers data from an observerrated measure of emotional processing during therapy, the client's perceptions of change as measured by post-session and post-therapy questionnaires, the therapist's perceptions of change as measured by post-session reports, and post-therapy interview data, to form an understanding of factors that contributed to change. Eloise's case study is designed to compare and contrast with Watson, Goldman, and Greenberg's (2011) case study of Tom, a poor-outcome case drawn from a similar RCT. The Eloise and Tom case studies extend and build upon the cases presented by the authors of Case Studies in Emotion-Focused Treatment of Depression: A Comparison of Good and Poor Outcome (Watson, Goldman, \& Greenberg, 2007), which consist of three good outcome and three poor outcome clients compared and contrasted using the case-comparison method.
\end{abstract}

Key words: emotion; case study; experiential therapy; depression; randomized clinical trials (RCTs); emotion-focused therapy (EFT); case studies; clinical case studies; comparative case studies

\section{CASE CONTEXT AND METHOD}

\section{Overview}

This is the case study of "Eloise," a good-outcome client who was drawn from the emotion-focused therapy (EFT) condition of a randomized clinical trial (RCT), the "York II Depression" study (Goldman, Greenberg \& Angus, 2006). Eloise's case study is designed to compare and contrast with Watson, Goldman, and Greenberg's (2011) case study of "Tom," a poor-outcome case drawn from a similar RCT. Like Watson's study of Tom, the present case 
Contrasting Two Clients in Emotion-Focused Therapy for Depression 2:

The Case of "Eloise," "It's Like Opening the Windows and Letting the Fresh Air Come In"

R.N. Goldman, J.C. Watson, \& L.S. Greenberg

Pragmatic Case Studies in Psychotherapy, http://pcsp.libraries.rutgers.edu

Volume 7, Module 1, Article 3, pp. 305-338, 06-05-11 [copyright by authors]

study of Eloise draws on a variety of collected data to help determine the individual elements of treatment that may have led to positive therapeutic outcome. The cases of Eloise and Tom are intended to expand upon the individual cases in Case Studies in Emotion-Focused Treatment of Depression: A Comparison of Good and Poor Outcome (Watson, Goldman, \& Greenberg, 2007). The present study uses an analogous case-comparison method to describe the implementation of emotion-focused therapy.

Descriptions of the specific measures used in Eloise's case study are presented below.

\section{The Emotion Episode (EE) Process Measure}

The Emotion Episode (EE) measure was developed by Korman (1991, 1998), and further elaborated and studied by Goldman (1997), Greenberg \& Korman (1993), and Pos, Greenberg, Goldman, \& Korman (2003). The measure defines an EE as a segment of psychotherapy in which a client speaks about having experienced emotion in response to a situation, real or imagined. The EE segment is complete when the narrative theme changes or a new emotional response is being expressed. An EE contains five components: the situation (e.g., loss of a loved one), an emotional response (e.g., sadness), a tendency toward behavior or action associated with emotion (e.g., crying), an appraisal of self or situation (e.g., "I’m alone," or "She's gone forever"), and a related concern or need. For an EE to be identified, only the emotional response or action tendency and a reported situation are required. Emotional responses are coded according to a list of 15 possible emotions. EEs typically range from one to two and a half pages of transcript in length or 250-400 words. High inter-rater reliability for the EE measure has been established (e.g., Pos et al., 2003).

An example of a brief client EE and a list of possible emotions are presented in Appendix 1. (For further information and exemplars of EEs, see Greenberg and Korman [1993].) Raters identified EEs from the course of Eloise's therapy, drawing from the 15 emotions listed in Appendix 1. Emotion episodes were tracked across the entire case.

\section{Self-Report Post-Session Measures}

The following self-report measures were administered directly after each session.

\section{General Session Evaluation Questionnaire (GSEQ).}

This measure assesses client's evaluation of the session. It consists of five items, three taken from Orlinsky and Howard's (1975) Therapy Session Evaluation Measure. The three items were put forth by Orlinsky and Howard as a session evaluation measure to be administered at the end of every session (Orlinsky, 1988). The three items are highly intercorrelated. Clients are asked to rate three questions on a Likert scale ranging from 1 to 7 : how they feel about the session they just had, how helpful they found their therapist, and how much progress they feel they made in dealing with their problems. In addition, two items ask clients to rate whether something changed in the session and their perceived likelihood of taking alternative actions as a 
Contrasting Two Clients in Emotion-Focused Therapy for Depression 2:

The Case of "Eloise," "It's Like Opening the Windows and Letting the Fresh Air Come In"

R.N. Goldman, J.C. Watson, \& L.S. Greenberg

Pragmatic Case Studies in Psychotherapy, http://pcsp.libraries.rutgers.edu

Volume 7, Module 1, Article 3, pp. 305-338, 06-05-11 [copyright by authors]

result on a 7-point Likert scale ranging from 1 (not at all or unlikely) to 7 (very much or very likely) Space is given after these last two questions for clients to write in a response. Thus, for example, if they feel something has changed in the session, they are asked to indicate what, and if they think they are likely to engage in alternative action, they are asked to indicate what that might be. Answers to these questions reveal topics and the content focus for the particular session. Inter-item reliability for this scale is .83, as determined by using the original sample from a larger outcome study (Watson \& Greenberg, 1998).

\section{The Beck Depression Inventory - Short Form (BDI, Short Form)}

The BDI is a 12-item short form of the Beck Depression Inventory that is used to assess the presence of depressive symptoms (Beck, Steer \& Garbin, 1987). Following Watson, Goldman, and Greenberg (2011), we interpret scores of 1-10 to indicate no depression; scores of 10-15, to indicate mild depression; and scores of 15 or higher, to indicate severe depression.

\section{The Working Alliance Inventory (WAI)}

The Working Alliance Inventory (WAI) (Horvath \& Greenberg, 1989) is based on Bordin's (1979) tri-partite conceptualisation of the client-therapist relationship as comprised of goals, tasks, and bonds. The inventory consists of 12 items, 4 from each subscale. Each item is designed to tap the agreement between therapist and client on goals, the degree of concordance on tasks, or the strength of the bond. Internal consistency for the scale ranges from .87 to .93 and is high for subscales (.89 for Goal, .92 for Task, and 92 for Bond) (Horvath \& Greenberg, 1989). Reliability data for the WAI has revealed a test-retest index of .83 (Horvath, 1994). This measure was administered at the end of each session.

\section{Therapist Post-session Questionnaire (TPSQ): Degree of Resolution Scale}

After each session, therapists are asked whether an EFT task was undertaken, and if so to rate the degree to which it was resolved on a 6-point scale, specific to that task. The relevant tasks undertaken in this therapy case that have degree of resolution scales associated with them are the two-chair task for a negative self-evaluative conflict splits and the empty chair task for unfinished business with a significant other. On each scale, a rating of (1) indicates the appearance of a marker, ratings of (2), (3), and (4) represent completion of the first three stages of the model, (5) represents a turning point or significant change, such as a critic has softened or a separation from the other has occurred as in unfinished business. A full resolution receives a rating of 6. The type of resolution is specific to each task, and involves full self-acceptance for the two-chair conflict split task and that a person feels more powerful or forgives and accepts the significant other in the unfinished business task. These reports indicate what has been the content focus for the particular session and how much progress has occurred. They can also consensually support or contradict client post-session reports. 
Contrasting Two Clients in Emotion-Focused Therapy for Depression 2:

The Case of "Eloise," "It's Like Opening the Windows and Letting the Fresh Air Come In"

R.N. Goldman, J.C. Watson, \& L.S. Greenberg

Pragmatic Case Studies in Psychotherapy, http://pcsp.libraries.rutgers.edu

Volume 7, Module 1, Article 3, pp. 305-338, 06-05-11 [copyright by authors]

\section{Self-Report Outcome Measures}

The client was assessed on outcome measures one week prior to and at the end of therapy. The four measures included are described below.

\section{Beck Depression Inventory - Long Form}

The long form of the BDI was used as an outcome measure. It is composed of 21 questions or items, each with four possible responses. Each response is assigned a score ranging from zero to three, indicating the severity of the symptom. Items 1 to 13 assess symptoms that are psychological in nature, while items 14 to 21 assess more physical symptoms. Scores may range from 0 to 63. Internal consistency for the BDI ranges from .73 to .92, with a mean of .86. The measure correlates highly with other self-report measures of depression (Beck, Steer, \& Garbin, 1988).

Symptom Checklist-90-Revised (SCL-90-R; Derogatis, 1983)

The SCL-90-R is a widely used 90-item self-report inventory that measures general symptom distress and common psychiatric symptoms. Participants respond to the amount of distress they experience on a 5-point Likert scale ranging from 0 (not at all) to 4 (extremely). Its internal consistency estimates for all nine subscales range from .77 to .90, with test-retest reliability for a one-week interval ranging from .80 to .90 (Derogatis, Ricket, \& Roch, 1976). Concurrent and discriminative validity for the SCL-90-R (Schmitz, Kruse, Heckrath, Alberti, \& Tress, 1999), and SCL-90-R depression subscale have also been established (McGough \& Curry, 1992). In the present study, the Global Severity Index (GSI) of the SCL-90 was employed. The GSI is designed to measure overall psychological distress and common psychiatric symptoms.

Inventory of Interpersonal Problems (IIP; Horowitz, Rosenberg, Baer, Ureno, \& Villasenor, 1988)

The IIP is a self-report instrument consisting of 127 items. Responses are scored using a 5-point Likert scale with responses ranging from 0 to 4 . It is used to measure the severity of distress arising from interpersonal sources. Respondents rate the degree to which each situation is experienced as being problematic. The authors report overall test-retest reliability between .89 and .98, and internal consistency ranging from .89 to .94 (Horowitz et al., 1988). With respect to validity, the IIP has been shown to be sensitive to clinical change and has correlated well with alternative measures of clinical improvement, including the SCL-90 (Horowitz et al., 1988).

\section{$\underline{\text { Rosenberg Self-Esteem Inventory (RSE; Rosenberg, 1965) }}$}

A 10-item version (Bachman \& O’Malley, 1977) of the RSE was used to assess clients' levels of self-esteem. This instrument has shown good internal consistency and validity. Excellent internal reliability (.89 -.94), test-retest reliability (.80-.90), and adequate sensitivity to change have been reported. 
Contrasting Two Clients in Emotion-Focused Therapy for Depression 2:

The Case of "Eloise," "It's Like Opening the Windows and Letting the Fresh Air Come In"

R.N. Goldman, J.C. Watson, \& L.S. Greenberg

Pragmatic Case Studies in Psychotherapy, http://pcsp.libraries.rutgers.edu

Volume 7, Module 1, Article 3, pp. 305-338, 06-05-11 [copyright by authors]

\section{Post-Therapy Assessment Interview}

One week after the cessation of therapy, clients underwent a post-therapy change interview that tapped into their subjective experiences and impressions of change. Clients were first asked whether they believed they had changed during the course of treatment. If the answer was positive, they were asked to specify and elaborate on the nature of those changes and to what they attribute the changes (events occurring within or outside of therapy). They were also asked whether they felt their depression was alleviated, about the themes of the therapy, and about critical incidents or specific moments that they could recall in association with changes. If they did not feel they had changed during therapy, they were asked to elaborate on what may have prevented change from occurring.

\section{The Therapist}

The therapist was a 54 year-old male with approximately 25 years of clinical experience who served as one of the main creators of Emotion-Focused Therapy.

\section{THE CLIENT}

The case that was drawn from the York II Depression study, which compared the effectiveness of Emotion-Focused and Client-Centered treatment approaches for a sample of 38 depressed clients (Goldman, Greenberg \& Angus, 2006). "Eloise" was a 38 year-old woman who came to therapy because of what she felt was becoming a debilitating depression. She found herself increasingly isolated and lacking in motivation. She was married but had no children. When therapy began, she was working for the telephone company, but felt unsatisfied with her work. She wanted therapy to help her alleviate depressive symptoms and manage her family. She was also considering a change in job status and returning to school for re-education. She had a past history of anorexia nervosa and had suffered two prior depressive episodes. Her current diagnosis consisted of General Anxiety Disorder with a Global Assessment of Functioning score of 55 .

\section{THE GUIDING CONCEPTION: EFT FOR DEPRESSION}

The guiding conception employed with the case of Eloise is the same one employed in the case of Tom by Watson, Goldman, \& Greenberg (2011), in this issue of the PCSP journal. Below is a summary of EFT from that article. More details about the EFT model are provided in the Watson et al. (2011) article.

In EFT, depression is seen to result from problems in affect regulation as a result of maladaptive, blocked, and unprocessed emotional experience (Greenberg, Elliot, \& Foerster, 1990; Greenberg \& Watson, 2005; Watson, Goldman \& Greenberg, 2007). A goal of EFT therapists is to help clients access and process their emotional experiences and construct new meanings and ways of being in the world. A primary objective in EFT is to change the emotion schemes underlying clients' depressions by deepening their experiencing and 
Contrasting Two Clients in Emotion-Focused Therapy for Depression 2:

The Case of "Eloise," "It's Like Opening the Windows and Letting the Fresh Air Come In"

R.N. Goldman, J.C. Watson, \& L.S. Greenberg

Pragmatic Case Studies in Psychotherapy, http://pcsp.libraries.rutgers.edu

Volume 7, Module 1, Article 3, pp. 305-338, 06-05-11 [copyright by authors]

emotional processing. There is some evidence that helping clients access and process their emotional experience in the session is related to good outcome (Goldman, Greenberg, \& Pos, 2005; Greenberg \& Watson, 1998; Watson, Gordon, Stermac, Steckley \& Kalogerakos, 2003). Furthermore, emotional arousal and deeper experiencing are significantly related to outcome in the resolution of client depression and unfinished business (Pos, Greenberg \& Goldman, 2003; Greenberg \& Foerster, 1996; Greenberg \& Malcolm, 2003; Paivio \& Greenberg, 1998; Watson \& Bedard, 2006).

\section{ASSESSMENT}

Eloise answered an ad in her local newspaper that called for participants to take part in a psychotherapy research study for the treatment of depression. At the assessment interview, Eloise tearfully reported feeling so down and depressed that she had finally decided to do something about it. Eloise had been depressed for most of her life but noted that

... this has been a particularly bad year. I just feel that even though I have had crises in the past with depression, I've always seemed to be able to bounce back, you know? And I'm having a hard time this time.

In the previous year, she had not worked, falling into a pattern of rarely leaving the house or answering the phone or the door. This was the first time that she had sought therapy for her depression.

When she entered therapy, Eloise was married. However, her husband, who also suffered from depression, had been hospitalized against his will after Eloise's sister called the police because of his unpredictable and apparently violent behavior. As a result of the police intervention, her husband was prohibited from living in the home or having contact with Eloise for a number of months. In the year prior to entering therapy Eloise experienced two significant losses: a good friend died of AIDS, and her brother-in-law, one of her closest family members, died suddenly.

Eloise's relationships with family members were difficult and often painful. Her mother was an alcoholic from whom she and her three sisters had severed contact. Her father was a concentration camp survivor. He was emotionally disengaged from the family, critical, and judgmental. Eloise recalled a history of physical punishment throughout her childhood. All four sisters left the family in their mid-teens; Eloise was fifteen when she left home. She first went to live with her middle sister and her husband, but then lived on her own as she finished high school and college. After college she lived with her oldest sister and her brother-in-law. She considered her sisters the most important part of her family, and she often saw her oldest sister and brother-in-law as surrogate parents, as they provided her with the affection and support that she did not get from her parents.

Throughout her childhood and into her adult life, Eloise experienced herself as alone and unsupported. She internalized the critical voices of her parents and often judged herself to be a failure. As a result of her physically and emotionally abusive past, she often felt emotionally 
Contrasting Two Clients in Emotion-Focused Therapy for Depression 2:

The Case of "Eloise," "It's Like Opening the Windows and Letting the Fresh Air Come In"

R.N. Goldman, J.C. Watson, \& L.S. Greenberg

Pragmatic Case Studies in Psychotherapy, http://pcsp.libraries.rutgers.edu

Volume 7, Module 1, Article 3, pp. 305-338, 06-05-11 [copyright by authors]

unsafe and abandoned. She saw herself as unloved, "a fact” that she believed was never going to change and over which she had no control. In contrast to her view of her life as chaotic, she had the sense that her siblings' lives were easier. She felt hopeless.

\section{FORMULATION AND TREATMENT PLAN}

Eloise was treated with Emotion-Focused Therapy (EFT), developed by Greenberg, Elliott, Watson, Goldman and associates (e.g., Watson, Goldman, \& Greenberg, 2011, in this issue). In line with the EFT model outlined in Watson, Goldman, and Greenberg (2011), case formulation in EFT involves a global assessment of the client's style of emotional processing, identification of the client's characteristic style of treating him- or herself, and potential tasks to resolve interpersonal and intrapersonal issues and to promote more effective affect regulation. Case formulation is not conducted prior to treatment and is a moment by moment process that begins in the first session as clients describe their presenting problems, current context, and life histories. Case formulations are co-constructed by clients and therapists in the early sessions and continues throughout treatment. For a fuller description of the case formulation process in EFT, see Greenberg \& Goldman, 2007

\section{Problems and Goals}

Eloise's style of emotional processing was to avoid painful and difficult emotions. She felt overwhelmed by her emotions; however, she was able to become aware of her emotional experience in the session, label it, and focus on it when her therapist responded empathically. Eloise's dominant emotion scheme was that of helplessness and hopelessness, especially when she experienced a need for closeness and acceptance. The first goal of the therapy, then, was to address her tendency to avoid painful, difficult emotions, including helplessness and hopelessness. Ultimately the goal was to address the maladaptive emotions that underlie this sense of resignation, such as perhaps fear and shame, and replace them with more adaptive ones so that she could feel more confident, access support, and allow herself to get close to others. At the beginning, however, the therapist did know the content of all of her underlying emotions. This is a process of discovery. The therapist did become aware, however, of her avoiding difficult emotions, though, and would like to facilitate the client to gain access to them.

Eloise felt like a failure. The second goal was to attend to the way she treated herself. She was very self-critical and felt criticized by family members. In addition, her therapist hypothesized that she had unfinished business stemming from her early relationship with her father, given the effect of her unexpressed resentment and sadness toward him on her sense of self-worth.

The third goal of the treatment for Eloise was to resolve her relationship with her father, redistribute responsibility, and form a new view of her father that would involve a new understanding of self and an improved sense of self-worth. 
Contrasting Two Clients in Emotion-Focused Therapy for Depression 2:

The Case of "Eloise," "It's Like Opening the Windows and Letting the Fresh Air Come In"

R.N. Goldman, J.C. Watson, \& L.S. Greenberg

Pragmatic Case Studies in Psychotherapy, http://pcsp.libraries.rutgers.edu

Volume 7, Module 1, Article 3, pp. 305-338, 06-05-11 [copyright by authors]

\section{Treatment Plan}

In EFT, two important procedures that are employed in the therapy room are the "twochair" technique and the "empty chair" technique. These were utilized in Eloise's case. In twochair work, one part of the self is instructed to express the harsh criticism or negative selfstatements in order to evoke the emotional reactions to the criticisms. These reactions, such as hopelessness, fear, or shame, are transformed by accessing alternate, more primary emotions such as sadness at loss or anger at violation. These feelings are accessed by focusing on current primary emotions and articulation of needs. Clients are encouraged to symbolize and express primary feelings and associated needs and use these to combat their negative cognitions. This leads to a softening of the harsh criticism and a negotiation and integration of the two previously disparate aspects of self (Greenberg, Rice, \& Elliott, 1993). For Eloise, the two-chair technique was used to work through feelings of failure and ultimately arrive at a new self-confidence.

The two chair technique can also be used when one part of the self is interrupting the other and with the aim of allowing emotional expression. Here the person becomes aware of the variety of modes (cognitive, schematic, physiological) by which s/he is disallowing emotional expression and is supported to alternatively allow emotion and the expression of associated needs. For Eloise, this was an important technique used to help her allow her expression of anger to which she had not felt entitled, as well as more vulnerable needs that she had learned to suppress out of fear, and self-protection.

Empty chair work for unfinished business involves the expression of previously suppressed primary emotion such as hurt and anger to the imaginary significant other in the chair. This leads to an expression of unmet needs. Clients take the perspective of the other at this point in the dialogue, which leads them to access a new view of the other. Resolution has been shown to involve an assertion of the self and an understanding of the other and a letting go, forgiveness, or affirmation of the other's accountability for his or her actions (Greenberg \& Malcolm, 2002).

For Eloise, empty chair work was used to address her unfinished business stemming from her early relationship with her father. Empathic responding by the therapist was also seen as important in order to help Eloise become more aware of her emotional experience, symbolize it, and process it so that she would not be overwhelmed by it. The overall objectives and themes throughout the therapy were resolving Eloise's internal conflict split and improving her familial relationships.

\section{COURSE OF THERAPY}

The 10 sessions of the therapy mapped meaningfully onto the three phases of EFT that are described in the Guiding Conception section of Watson, Goldman, \& Greenberg, 2011, including bonding and awareness, evoking and exploring phase; and transformation. 
Contrasting Two Clients in Emotion-Focused Therapy for Depression 2:

The Case of "Eloise," "It's Like Opening the Windows and Letting the Fresh Air Come In"

R.N. Goldman, J.C. Watson, \& L.S. Greenberg

Pragmatic Case Studies in Psychotherapy, http://pcsp.libraries.rutgers.edu

Volume 7, Module 1, Article 3, pp. 305-338, 06-05-11 [copyright by authors]

\section{Sessions 1-3. The Bonding and Awareness Phase}

\section{$\underline{\text { Session } 1}$}

The first three sessions fell directly into the bonding and awareness phase. Specifically, in the first session the client described her feelings of pain and hopelessness. She felt defeated and lacked the energy to cope with her family: "Basically I want them to leave me alone. That's how I feel. Christmas is coming and I dread it.” She described her relationship with her sisters as very difficult, saying, "I've just got to the point now where I don't care anymore. I just want them to leave me alone. It's too emotionally draining.” The client reported that she felt very alone and would resort to sleep to escape her feelings of loneliness. Although she longed for her family's approval, when she began to feel strong emotions about her need to be supported and accepted by her family, she was immediately overwhelmed by the thought that it would never happen, and that she did not deserve such intimacy because she was a failure.

As described above, “emotion episodes” were tracked across the case. These are moments in therapy in which a client describes an emotional reaction to a stated situation. As seen in Figures 1 and 2, throughout the first session the client expressed many such emotion episodes of pain and anger that were followed by feelings of helplessness or hopelessness. In fact, hopelessness constituted almost $50 \%$ of all emotion episodes in the first session. At the end of the session the client completedthe General Session Evaluation Questionnaire (GSEQ; see above description under "Self-Report Post-Session Measures"), in which she identified "feelings of isolation and rejection" as the main concern that she had focused on in therapy. She also said that she would like to be less emotional and not allow "things people say to affect her feelings about herself."

The therapist and client spent the first few sessions establishing the major issues and themes that related to Eloise's current depression. The therapist followed Eloise's lead, allowing her to direct the process with no specific agenda in mind. The therapist's main objective at that time was to listen to the client unfold her current experience of being in the world and help her identify what was bothering her most, as well as observe her emotional processing style. Eloise's therapist used empathically guided validations, explorations to communicate understanding to the client. During this time, the therapist highlighted certain issues as important and began to develop an agreement with Eloise about the issues that they would explore further. As stated in the Guiding Conception, a strong alliance that includes an agreement on the tasks and goals of the treatment and a shared bond is essential to the success of Emotion-Focused Therapy. Beyond the first few sessions, however, which are spent establishing the goals and tasks of therapy, the alliance is typically not explicitly addressed unless there is a breakdown or a mistaken attunement on the part of the therapist.

\section{$\underline{\text { Session } 2}$}

In session two the client began to explore her feelings of sadness and depression. She described a history of not having worked and how hard it was for her to think about being around 
Contrasting Two Clients in Emotion-Focused Therapy for Depression 2:

The Case of "Eloise," "It's Like Opening the Windows and Letting the Fresh Air Come In"

R.N. Goldman, J.C. Watson, \& L.S. Greenberg

Pragmatic Case Studies in Psychotherapy, http://pcsp.libraries.rutgers.edu

Volume 7, Module 1, Article 3, pp. 305-338, 06-05-11 [copyright by authors]

people. She began to examine how expectations that others might have of her, including that she would hold one end of a conversation, felt overwhelming. She described her relationship with her sisters, saying:

I don’t feel close to my family, even like with my sisters. They all got married very young, they all had children, and their children have children. I'm sort of like the nomad in the family; I didn't get married til I was 36. I moved around a lot, it was just a different type of life than what they had.

She described feeling like an outsider, as she was ostracized by her family. She saw this exclusion from her sisters' lives as the core of her experience of depression and sadness.

This dialogue transitioned into a discussion about returning to school or work. She described how she had been home for the past year. Previously she had been employed in a technical field, but she felt that this work was unfulfilling and wanted to find employment in a position that might be of more interest to her. However, she was not sure that she was capable.

Client: Yea, I'm thinking I've been off work for almost a year-it'll be a year the end of December, so I'm thinking it's time. It's time to sort of get out there and try to be around people again.

Therapist: So you would like to get back to work?

C: Yea, trying to get some focus and I don't know if this is a good time to do it, I don't know if I'm in the right state of mind to make any big major decisions that way because going back to school is a real commitment. I've been out for a while. I mean I enjoy school but I realize it's a big commitment and needs....The other part is because of my emotional state right now.

T: So you are not sure you can handle it right now?

C: I don't want the stress, and also I don't want to invest the dollars and then find that it's too overwhelming. It just doesn't seem worth it. What is this all about and why am I trying to be something? I don't know what I'm trying to be. I'm thinking of going back to school, so another diploma on the wall. Like why am I doing this?

Eloise explored her fears about being able to manage this change emotionally and the possibility of failure. She quickly became hopeless in the face of the further possibility for failure in the eyes of her sisters.

C: Yea, unsupported, I feel inferior to them, I feel that I have no self-esteem left and it's like I don't want to try anymore with them. It's like okay you win, I'm not as good as you, you win and that's it. Fine, so leave me alone.

She discussed her experience of pain at being judged and feeling unsupported by her family and identified a pattern of feeling hurt and then withdrawing in order to protect herself from outside criticism. She also began to describe how this withdrawal left her feeling hopeless. As the session proceeded the therapist and the client began to identify a second voice that 
Contrasting Two Clients in Emotion-Focused Therapy for Depression 2:

The Case of "Eloise," "It's Like Opening the Windows and Letting the Fresh Air Come In"

R.N. Goldman, J.C. Watson, \& L.S. Greenberg

Pragmatic Case Studies in Psychotherapy, http://pcsp.libraries.rutgers.edu

Volume 7, Module 1, Article 3, pp. 305-338, 06-05-11 [copyright by authors]

expressed the needs and wants for the self (Elliott et al, 2004; Greenberg et al, 1993). This voice was vulnerable to criticism and yet carried the possibility of claiming the right to create her life. It expressed the hope that she might actually be "okay."

C: This is the rightest path I ever followed in my life now in being married and owning a house and I'm going to-what's the big deal? Like I enjoy being married but this whole thing of-I'd be just as easy to live in the woods in a little cabin.

T: There is a part that says, 'So what's the big deal?' This isn't being regular and doing the right thing in their eyes, isn't such a big deal. Somewhere there is another voice but it's a very vulnerable voice because it hurts so much to be told to think you didn't do the right thing and to feel like whoever you really are wasn't valued and supported. You were always being viewed with raised eyebrows and rolling eyes

C: Yea, and feel like I'm...

T: Like you've been judged as not really good enough. Then the only recourse right now is to just sort of say, well if you don't love me the way I am, if you don't approve of me, I'm just going to...

C: Go and live my life.

T: Go and live my life. It's a bit like, I'll take my marbles and go home and it hurts but I don't know what else to do.

C: Because it hurts more the other way.

T: It hurts more to come out and to have them disapprove of you. Somehow you feel...kind of depressed and withdrawn-it's a losing battle not quite being able to get the approval I want. I am not what they expected me to be. So that's why it hurts so deeply that it makes you feel like "I'm not good enough."

C: Yea, me and millions of others.

$\mathrm{T}$ : See yea, there is a bad disapproval. There is another voice.

C: Oh, yea. And it's always been there. I mean there was a time where I was-it was very verbal and I would fight back and say and stand up for myself and now I'm just like (sigh).

Here the client began to identify and separate the internalized voices of her family that had become the "critical voice" in her from the vulnerable voice of her experiencing self that expressed her needs and wants.

As shown in Table 1, at the end of this session the client received a score of 20 on the Beck Depression Inventory-Short Form. This represented a change of 20 points. The General Session Evaluation Questionnaire that she completed at the end of the session indicated that she had focused primarily on her "lack of self worth." Thus, her understanding of the focus had shifted from "feelings of isolation and rejection," to an awareness of the way in which those experiences impacted her understanding of her self. The client had begun the process of identifying the core emotional processes that were causing her difficulty, bringing forth new information about her experience. 
Contrasting Two Clients in Emotion-Focused Therapy for Depression 2:

The Case of "Eloise," "It's Like Opening the Windows and Letting the Fresh Air Come In"

R.N. Goldman, J.C. Watson, \& L.S. Greenberg

Pragmatic Case Studies in Psychotherapy, http://pcsp.libraries.rutgers.edu

Volume 7, Module 1, Article 3, pp. 305-338, 06-05-11 [copyright by authors]

\section{$\underline{\text { Session } 3}$}

At the beginning of the third session the client reported that she had expressed her needs to her sisters, particularly one of them, and identified the things that they had done that hurt her.

C: Oh, I told her that her tone of voice to me, the way she says things and the things, you know, I gave her a-you said this to me, you dumb this. Some things she acknowledged and other things she wasn't aware-like she wasn't aware that maybe she spoke to me in that tone of voice. You know, it's part her and part my perception also because I'm so sensitive, you know. Sometimes people just have to look at me and I think they're you know, so I mean I think I feel better because I think she will definitely make-I think she realizes my state of mind and how fragile I am and that's why they showed up, I think, because they were very concerned and I think she realizes that — she maybe has tonot- 'cause she did the same thing she feels like she has to tiptoe around me, but I think she's aware now that maybe just to watch what she's saying. I think we need to communicate there. We don't communicate well, you know.

The topic shifted and later in the session she partook in an empty chair dialogue with her father midway through the session. She began to express how unloved she felt.

C: It hurts me that you don't love me-yea-I ... guess, you know, but ... I'm angry at you and I needed love and you weren't there to give me any love.

As the dialogue progressed, the client gave full voice to her anger at the ways in which her father disappointed and hurt her. Following her anger, fear, and pain emerged, creating the opportunity for new information to be integrated into the client's experience of herself. She acknowledged the ways in which she had been wronged. This helped gird her against feeling hopeless.

The client continued the dialogue telling her father about her fear of him.

C: I was lonely. I didn't know my father. All I knew you as was somebody that yelled at me all the time and hit me. That's all-I don't remember you telling me you loved me or that you cared for me or that you thought that I did well in school or anything. All I knew you as was somebody that I feared.

The empty chair work continued with the therapist having the client heighten her experience of being hit. The client's emotional experience shifted to anger.

C: And he humiliated me. I was very angry with you because you were always hitting me, you were so mean and I heard Hitler was mean, so I called you Hitler.

Throughout the session the client's ability to stay with her own internal experience of anger fluctuated. She often interrupted the narration of her experience by laughing or making a joke, demonstrating her discomfort with her anger. 
Contrasting Two Clients in Emotion-Focused Therapy for Depression 2:

The Case of "Eloise," "It's Like Opening the Windows and Letting the Fresh Air Come In"

R.N. Goldman, J.C. Watson, \& L.S. Greenberg

Pragmatic Case Studies in Psychotherapy, http://pcsp.libraries.rutgers.edu

Volume 7, Module 1, Article 3, pp. 305-338, 06-05-11 [copyright by authors]

C: The only way I can handle it is by making a joke of it because it helps-it helps because when I'm too serious about it, I become so depressed I can't function. So I learned to laugh about it and you know I have that sarcastic humor and sort of jaded eye I guess about things.

The therapist encouraged her to look beneath the laughter and reflected:

T: Because underneath the laugh I guess there's a lot of hurt and a lot of hate.

The client continued to work in the empty chair situation with her experience of anger and was able to express to her imagined father:

C: I hate you. I hate you, there's no doubt about that in my mind. I've hated you for years. It angers me when I see you at family functions and I don't feel good being there and you act like nothing ever happened.

The client expressed pain and hurt at her father’s inability to make her feel loved, saying:

C: I guess I keep thinking that yeah, you will be a parent; that you would pick up the phone and just ask me how I'm doing. It hurts me that you don't love me.

She ended the session recognizing that what she needed was acceptance:

C: I needed to be hugged once in a while as a child or told that I was okay. I think that's normal.

Through the expression of pain, hurt, and anger, the client shifted her belief that her father's failure was not because she was not worth loving. The anger provided insight and support for her experience of having been denied something she deserved. As shown in Table 1, the client's depression score on the Beck Depression Inventory short form had declined from 20 at the end of the second session to 12 at the end of the third session. After session 3 she endorsed the statement of "I feel sad" on the Session Evaluation Questionnaire as opposed to "I am sad all the time and I can't snap out of it.” Her answers regarding failure also indicated a shift. The client reported, "I feel I have failed more than the average person," rather than her previous response, “As I look back on my life, all I can see is a lot of failures.”

\section{Sessions 4-5 (Part 1). The Evoking and Exploring Phase}

\section{$\underline{\text { Session } 4}$}

In the fourth session the client reported that she had enrolled in school as a full time student.

C: I registered for school, so I'll start school in January. I made a decision there-to which is sort of nice you know... I went and registered and said, 'Okay, now I'm committed.' So I'm looking forward to that. 
Contrasting Two Clients in Emotion-Focused Therapy for Depression 2:

The Case of "Eloise," "It's Like Opening the Windows and Letting the Fresh Air Come In"

R.N. Goldman, J.C. Watson, \& L.S. Greenberg

Pragmatic Case Studies in Psychotherapy, http://pcsp.libraries.rutgers.edu

Volume 7, Module 1, Article 3, pp. 305-338, 06-05-11 [copyright by authors]

However, she expressed a fear of failing that prompted her therapist to suggest a two-chair task to further explore these feelings: one chair represented her hopes, and the other, her fears. The client responded to her hopes and needs for achievement with a critical voice that suggested failure and triggered fear. The critical voice compared her to her sisters, claiming that she was not achieving enough. The voice said that she should settle down and earn money. A more experiential voice emerged that expressed a yearning for something meaningful in her life and rejected the need for status and accumulation of material goods.

C: I want to do something I guess that gives me satisfaction...To be good for people. I don’t necessarily think owning a cell phone and working for telecommunication is necessarily good for people. I want to do something more meaningful.

The session ended with the client identifying that she was quite excited to return to school and was beginning to feel much better. She expressed contentment and stated that therapy seemed to be working. On the GSEQ she stated that she felt like she had made moderate progress and was working to "not be so hard on herself". Her score on the Beck Depression Inventory-Short Form was 8 (see Table 1).

\section{Session 5, Part 1}

The fifth session was poignant as the client worked with the core maladaptive belief of not being lovable and with the emotional scheme of hopelessness that seemed to be activated when she wanted love. Her therapist suggested a two-chair technique to heighten the self-critical voice that pushed her toward depression in order to help her access an alternative, more supportive voice. Eloise agreed to engage in the task, and identified the critical voice as coming from her sister. She compared herself to her sisters or one of her sister's children and found herself lacking. She connected her feelings to the criticisms she heard from her parents.

Well, you're wrong, you're bad, you're-you never do anything right. Every time I ask you to do something you don't do it the way I want you to do it....and your marks are never good enough, and you're never on time, and you know you just-everything you do is wrong.

Heightening the critical voice triggered feelings of pain for Eloise. Her therapist continued to reflect her experience of herself and the client went on to say:

C: When I'm depressed, I believe it. I believe it wholeheartedly. That I'm bad and I'm wrong and I'm a loser. That's the big word, loser, that goes over and over, and then I'm a big loser and why can’t I just have a nice simple normal life?

The client described how this voice had followed her since childhood. The therapist encouraged her to tell the critical part of herself how wounded she felt. Eloise responded:

C: It makes me feel horrible, it makes me feel sad. It makes me feel unloved and not able to give love, you know. It makes me feel like I wish I'd never been born. 
Contrasting Two Clients in Emotion-Focused Therapy for Depression 2:

The Case of "Eloise," "It's Like Opening the Windows and Letting the Fresh Air Come In"

R.N. Goldman, J.C. Watson, \& L.S. Greenberg

Pragmatic Case Studies in Psychotherapy, http://pcsp.libraries.rutgers.edu

Volume 7, Module 1, Article 3, pp. 305-338, 06-05-11 [copyright by authors]

\section{Sessions 5 (Part 2)-10. The Transformation Phase: Generating New Meaning}

\section{$\underline{\text { Session 5, Part } 2}$}

The client began to recognize the impact of her critical voice and how it has affected her life. She stated that:

C: I realize what control it’s had over my life. It's been, God, I can't think of a year of my life where I haven’t gone through some point in that year a major depression.

The experiencing voice became much stronger in response to the heightened critical voice. The client then voiced her need for the critic to "go away for ever”. The experiencing voice responded to the critical voice by challenging the idea that she was a loser. As she asserts herself strongly toward the end of the two-chair dialogue, she says:

C: I know I am loved. I've always known that, I never believed it before. So I'm starting to believe that I am loved that it's just-instead of being angry because they don't love me, I'm just accepting that they just don't have the capacity to love. It wasn't just me, it was my younger sisters too. If any, it wasn't like they loved them and didn't love me, they didn't love any of us, not the way parents are supposed to love, there must be some kind of love there.

Here we see Eloise internally challenge the core belief that she was not worth loving.

Eloise expressed her sadness during this emotion episode at a consistently moderate level of emotional arousal so that her voice, body, and words conveyed her feelings. The feelings were present and discernible in the session, and she presented her emotional experiencing clearly, giving her personal, internal perspective. At this point in the therapy she was in the process of creating new emotional meaning with respect to her parent's inability to make her feel loved. She identified the way in which she gave voice to their behavior and supported the part of her that wanted to be loved.

After expressing her sadness and grieving her sense of not being loved, Eloise experienced contentment and relief (see quadrant 2 in Figures 4 and 6). The critical voice had begun to soften and both her sadness and her need to be loved are being integrated into her experience. The client stated:

C: Even though mom and dad didn't love me or didn't show me any love, it wasn't because I was unlovable, it was just because they were incapable of those emotions. They don't know how to....they still don't know how to love.

By this point in therapy, Eloise was no longer experiencing the hopelessness that had been so predominant in her earlier sessions (see quadrant 1, Figure 6). The primary maladaptive emotion scheme of hopelessness that seemed to get triggered when she felt unloved had presumably shifted. New emotional meaning has been created and the emotion scheme now more closely 
Contrasting Two Clients in Emotion-Focused Therapy for Depression 2:

The Case of "Eloise," "It's Like Opening the Windows and Letting the Fresh Air Come In"

R.N. Goldman, J.C. Watson, \& L.S. Greenberg

Pragmatic Case Studies in Psychotherapy, http://pcsp.libraries.rutgers.edu

Volume 7, Module 1, Article 3, pp. 305-338, 06-05-11 [copyright by authors]

reflected the idea that “My parents didn’t know how to love.” She continued to feel sad but not hopeless (see quadrant 2 in Figure 6). Sadness is seen as a healthy, adaptive emotion in this context whereas hoplessness is seen as maladaptive and unproductive (Greenberg, Auszra, \& Hermann, 2007).

At the close of session five, Eloise reported on the GSEQ that she had made "considerable progress". She wrote that the main concerns focused on in the session were her "inner negative voice" and others' "ability not to love." When asked what she would like to do differently as a result of the session, she stated that she would like to "be able to quiet the negative inner voice.” Her score on the Beck Depression Inventory-Short Form was 4 (see Table 1).

\section{$\underline{\text { Session } 6}$}

Session six began with Eloise talking about how much she was enjoying school. She then began to address her relationship with both of her parents. In this session she continued to experience anger towards her father for the ways in which he had hurt her. During an empty chair exercise, the therapist helped her heighten this anger. Eloise identified the ways in which her father physically abused her, ignored, and judged her. As she expressed the anger a number of things occurred. The client reported feeling a release in the tension caused by holding back her intense feelings about her father. As she allowed herself to be angry, she encountered new information that allowed her to acknowledge the ways in which her father was not a good father:

C: I'm angry at you because you think you were a good father, you have said that you never hit us and that's the biggest lie on earth. You beat the hell out of us constantly, you never showed any love, you never showed any affection, you never ever acknowledged we were ever there except for us to clean and do things around the house.

Prior to this session, she had interrupted the strength and intensity of her anger and she had not been able to say to her imaginary father in the other chair "you have not been a good father." Her ability to tolerate and stay with her experiences of pain, anger, and sadness (Figures. $1,2, \& 6$, respectively) toward her father increased. She was able to experience sadness (Figure 6) for not having felt loved. She also began to access feelings of calm and joy (Figures 4 \& 5, respectively) when her needs for closeness, love, and acceptance emerged. At this point in therapy the client was no longer experiencing symptoms within the clinical range of depression and had begun to make significant changes in the way she was communicating with her sisters.

\section{$\underline{\text { Session } 7}$}

By the seventh session Eloise was feeling very good about the effect that attending school was having on her life.

C: It's a challenge, you know, though it's a good challenge that I needed. Yeah, I needed this in my life. I needed something. 
Contrasting Two Clients in Emotion-Focused Therapy for Depression 2:

The Case of "Eloise," "It's Like Opening the Windows and Letting the Fresh Air Come In"

R.N. Goldman, J.C. Watson, \& L.S. Greenberg

Pragmatic Case Studies in Psychotherapy, http://pcsp.libraries.rutgers.edu

Volume 7, Module 1, Article 3, pp. 305-338, 06-05-11 [copyright by authors]

She continued to do well in school for the rest of the period she was in therapy and felt strong about her decision to attend school. Reflecting on her relationship with various family members, she said:

C: I think a large part has been dealt with my sisters. You know, I mean I still have my younger sister that I don't speak with but that's not even bothering me that much now. You know, I mean, because it’s just sort of like 'Oh, that will work itself out.'

The therapist inquired further to understand what further goals she had for therapy:

T: Then I guess there's the issue of, you know, whether we continue to work on the kind of underlying vulnerability issues which, um, aren't there when you're feeling up, you know.

In this session, they do continue working on feelings of vulnerability, and Eloise comes to realize:

C: You know, I have a tendency to allow myself to be like mortally wounded by words and I have to learn to just realize that they're just words. That's all they are. And to speak out at that time rather than letting things fester.

\section{$\underline{\text { Sessions 7-9 }}$}

Throughout sessions 7, 8, and 9, the client continued to engage in chair work to explore her sadness about her family's inability to make her feel loved, her anger over her family's judgment of her, and her hurt when she felt abandoned or alone. The emotional arousal associated with her anger was lower than in previous sessions.

In the eighth session she was able to allow herself to experience pain and continue experiencing it at a fairly high level of emotional arousal. For example, in an empty chair exercise with her sister, she stated:

C: I feel really hurt by the things you've said. I feel really hurt by your disapproval. By you thinking you're better than me. I feel really hurt by the things you've said about me to other people. I feel really hurt because for years while I was going around telling people how close we were, you were going around telling people what an asshole I was...I think I feel betrayed.

At the beginning of session nine the client stated:

C: I haven't had much time to think about things lately because I am so busy with school so I find that I'm not thinking about a lot of that other stuff, which is good in a way...Coming here really made a difference for me. I think the fact that, um, I started, I kept saying I needed help. I needed help. But I would never do it. 
Contrasting Two Clients in Emotion-Focused Therapy for Depression 2:

The Case of "Eloise," "It's Like Opening the Windows and Letting the Fresh Air Come In"

R.N. Goldman, J.C. Watson, \& L.S. Greenberg

Pragmatic Case Studies in Psychotherapy, http://pcsp.libraries.rutgers.edu

Volume 7, Module 1, Article 3, pp. 305-338, 06-05-11 [copyright by authors]

As session nine progressed the client began to explore the way in she turns anger at her family toward herself. She said :

C: I guess because maybe I get upset with myself because I don't want to need that. I guess because I think to myself, "I shouldn’t need anybody else to be okay."

She went on to explain:

C: I try to be, you know, I've been fairly independent most of my life because I have been alone most of my life. And I get angry, I guess, with myself when I do get into that, you know, that need. I hate being needy. I don't like needing. You know, I should, you know. I guess I want to do it on my own.

The client and the therapist worked to identify the ways she interrupted her need for love and feelings of vulnerability when her needs were not met. She said to her mother in an empty chair task:

C: I'm wasting time feeling bad because I want you, and you're not there. So it's best for me to shut my feelings off and not need them. That's what I do in my life. When people hurt me enough I get to that point where I actually can imagine, I literally cut them out of my life like I did with my mother.

Eloise then identified the way in which needing love made her vulnerable to hurt and pain, and how interrupting these needs left her vulnerable to isolation and loneliness. It was also in this period that Eloise explored the two different sides to her experience: the interrupting self that attempted to protect her through controlling and shutting off needs, and the experiencing self that wanted to be loved and accepted. She continued to define and speak from both voices and expressed a range of sadness, anger, and hurt. In this phase of therapy, the hopelessness that was so dominant in the early sessions was virtually non-existent (see Figure 6). The voice that wanted love and acceptance became stronger, and she began to give expression to her needs. She began to feel much better and had a harder time accessing negative feelings.

\section{$\underline{\text { Session } 10}$}

In the last session, session 10, the client and therapist engaged in another empty-chair dialogue with Eloise's father. Eloise began to soften and solidify her new understanding of her father.

C: I don't know if I feel resentment as much as I think by coming here, too, and talking about it, I think I've, I understand. I think my father went through a hard life. You know I think he went through war in Europe. He spent five years in concentration camps. I am sure that anyone who was in concentration camps saw horrendous things. I mean it was Auschwitz.

Later she said to her father in the empty chair, 
Contrasting Two Clients in Emotion-Focused Therapy for Depression 2:

The Case of "Eloise," "It's Like Opening the Windows and Letting the Fresh Air Come In"

R.N. Goldman, J.C. Watson, \& L.S. Greenberg

Pragmatic Case Studies in Psychotherapy, http://pcsp.libraries.rutgers.edu

Volume 7, Module 1, Article 3, pp. 305-338, 06-05-11 [copyright by authors]

C: I understand that you've gone through a lot of pain in your life and probably because of this pain, because of the things you're seen, you've withdrawn. You're afraid to maybe give love the way it should be given and to get too close to anybody because it means you might lose them. You know, and I can understand that now, whereas growing up I couldn't understand

As the session progressed the client continued to hold her father accountable for the ways that he disappointed and hurt her. She allowed her compassion to be central in the development of a new understanding of his inner struggles:

C: You know, being a concentration camp victim had a real impact on you. Instead of being a teenager, you're a prisoner of war. It obviously had a lasting impact on you and then as life went on and, you know, your marriage, ah, you know, I'm sure in the beginning it was good, you know I think at one point, mom and dad did at one point really love, um, each other, but I think with my mother's drinking, and maybe with some of the anger that you had about your life, and then you lost your child, your son, that um, your way of dealing with things was to be cold: to be unfeeling, to not be supportive, not that you didn't want to be. I don't think you know how.

In talking about the dialogue at the end of the session, the client says:

C: I feel relief that I don’t have this anger sitting on my chest anymore.

On the GSEQ, after session 10, Eloise reported that her main concern that she had identified in session 2 , had shifted from "My relationship with my father," to "Making peace with my father.” She stated:

C: Yeah, yeah, the anger's gone. Like, a lot of times I would avoid seeing anybody 'cause I was just so pissed off at them all.

Emotion Focused Therapy (EFT) posits that change in unfinished business occurs "through the arousal and expression of emotion and associated needs" (Greenberg et al, 1993). Through this process there occurs a strengthening of the self and the client is now able to identify previously less salient and often more positive aspects of the other. Throughout all of the previous sessions, the client worked to express her hurt, anger, and pain. She was supported and encouraged by her therapist to allow her emotions to run their course without interrupting them. Through this process she developed empathy and compassion for her father and the struggles that he had faced in his life that in turn prevented him from being emotionally available to meet her needs. The process of giving voice to her emotions strengthened her sense of legitimacy in needing to feel loved and supported, as well as her sense of hurt at feeling unloved. The client developed compassion for the struggles in her father's life. Expressing herself to her father in the empty chair, she states:

C: I can really understand or I can try to feel your pain and understand that, ah, you did the best you could knowing what you knew. 
Contrasting Two Clients in Emotion-Focused Therapy for Depression 2:

The Case of "Eloise," "It's Like Opening the Windows and Letting the Fresh Air Come In"

R.N. Goldman, J.C. Watson, \& L.S. Greenberg

Pragmatic Case Studies in Psychotherapy, http://pcsp.libraries.rutgers.edu

Volume 7, Module 1, Article 3, pp. 305-338, 06-05-11 [copyright by authors]

At the end of te session, Eloise expresses an emotion episode defined by a sense of calmness and relief. When asked by the therapist what she felt, the client responded:

\section{C: I feel relief. I feel relief that I don’t have this anger sitting on my chest anymore.}

The client went on to describe how she can now accept that her father doesn't have more to give. This led to emotion episodes of pride and then joy for having overcome these feelings. Eloise now felt a stronger sense of adequacy and much more able to communicate her needs to her sisters.

\section{THERAPY MONITORING AND USE OF FEEDBACK INFORMATION}

The therapy was monitored via the measures collected during and after each session, as described in the first section above, and via peer supervision of the therapist. By session 11, Eloise was endorsing items on post session measures indicating that issues she had identified as problematic had shifted since the start of therapy. By session nine, she discussed terminating therapy. Even though she was involved in a psychotherapy research study that allowed for 16 sessions of therapy, the decision was made, together with her therapist, that the major issues that brought her to therapy had been resolved. Session 10 was the last working session and she finished therapy after session 11, a wrap-up and summarizing session.

\section{CONCLUDING EVALUATION OF THERAPY'S PROCESS AND OUTCOME}

Session measures tracked client progress across therapy and outcome measures were administered at the end of therapy, along with the Post-Therapy Assessment Interview. In the following section, changes in Eloise's symptoms of depression and the main issues formulated for the therapy are addressed. Throughout the discussion, an emphasis will be upon the relationship of the therapy process to the outcomes of reduced depression and increased adaptive emotional functioning.

\section{Alliance}

The therapist worked within an empathic framework throughout the treatment and was careful to communicate acceptance and prizing of all of the client's experience. As seen as Table 1 , the WAI was scored at 6.25 , out of a maximum score of 7 , after session 1 and quickly strengthened more in subsequent sessions. It remained high throughout therapy. This suggests that a solid, trusting relationship was the backdrop that allowed the client to explore vulnerable emotions that she had previously felt unable to access on her own prior to therapy. Post-therapy data also indicate that the client trusted and felt safe with her therapist. At the Post-Therapy Assessment Interview, she stated, "I really felt that I was taking a chance. But then I kept saying 
Contrasting Two Clients in Emotion-Focused Therapy for Depression 2:

The Case of "Eloise," "It's Like Opening the Windows and Letting the Fresh Air Come In"

R.N. Goldman, J.C. Watson, \& L.S. Greenberg

Pragmatic Case Studies in Psychotherapy, http://pcsp.libraries.rutgers.edu

Volume 7, Module 1, Article 3, pp. 305-338, 06-05-11 [copyright by authors]

to myself, 'Of course I could always drop out,' but then I found Dr. X genuinely an easy person to be with.”

\section{Depression}

The client reported significant shifts in her level of depression each week, as indicated on weekly BDI reports and an absence of depressive symptoms within seven sessions. As shown in Table 2, her score was 20 after the second session, 12 after the third session, 8 after the fourth session, 4 after the fifth session, 2 after the sixth session, and 1 after the seventh session. For the remaining four sessions Eloise reported a score of 0. In the Post-Therapy Assessment Interview, when asked about her depression, she responded,

C: It seems to be gone. I mean, there are moments where something will go, but I wouldn't call it depression, it's just sort of like a sad thought will go through my mind or something. Like I said, it’s just fleeting, but I haven’t been depressed in quite a while.

She also said,

C: I think that I am still the same person and I think there will be periods of my life where I might have low periods, but what I think has happened for me is that I don't take them as seriously any more. I think the difference is that I feel that I have the strength now to recognize it, number one. When it's starting to happen I am able to pull myself out of it very quickly and just say, "It's just a thought, it's not reality, let it go and move on from there." I think that's the difference for me now is that when these things pop into my head, I go it's just a stupid thought and let it go, it's not worth my time any more.

When asked by the interviewer how likely change would have been if she had not come to therapy the client responds:

C: I think in my heart, I think if I hadn’t pulled, if I hadn’t gone to therapy, I would probably be in that same state. I think I'd still be going through the same cycle or I might be dead because I was thinking about suicide a lot.

Later, Eloise she elaborated on her changes and her perspective on the change process:

C: It's the whole verbalization...because it wasn't anything different than what I had been telling myself in my head for years and years and years. It was the actual hearing it said again and realizing that the impact this had on me and how I had allowed it to consume me and how-what a waste of time. It all came out of that. What a waste of time, my God, it was only words. And you allowed this to just ruin you inside, you know. So, I think, I think it did, yeah, because otherwise the story would still be dancing in my head. It would have never, it's like opening the windows, and letting fresh air come in. 
Contrasting Two Clients in Emotion-Focused Therapy for Depression 2:

The Case of "Eloise," "It's Like Opening the Windows and Letting the Fresh Air Come In"

R.N. Goldman, J.C. Watson, \& L.S. Greenberg

Pragmatic Case Studies in Psychotherapy, http://pcsp.libraries.rutgers.edu

Volume 7, Module 1, Article 3, pp. 305-338, 06-05-11 [copyright by authors]

\section{Shift in Maladaptive Emotions}

Overall across the sessions, episodes of joy and calm or relief and joy increased (Figures $4 \& 5$, respectively) as pain and hurt (Figure 1) and fear and anxiety (Figure 3) decreased. This is most significant in the last two sessions of therapy in which pain or hurt was not expressed, but calm or relief was expressed in one third of the emotion episodes. Hopelessness was expressed in $30 \%$ of the emotion episodes in the first three sessions and not present after that. The experience of sadness seemed to vary directly with that of hopelessness; as the hopelessness decreased, the sadness increased (see Figure 6).

In the second half of therapy, expressed emotion episodes had shifted. In sessions six through nine, anger accounted for 32\% of the emotion episodes (Figure 2), while sadness and pain each accounted for $21 \%$ of emotion episodes (Figure 1). Joy represented $11 \%$ (Figure 5) and calm or relief, $5 \%$ of emotion episodes (Figure 4). In the final two sessions, anger, sadness, joy, calm, and relief were the emotions that the client expressed. Anger and relief each made up $33 \%$ of the emotion episodes in the last two sessions (Figure 2 and 4 ).

Eloise described the emotional changes she had made by the end of therapy as being more able to "let things go" and not become stuck in negative feelings. She reported that her anger was gone. She observed that,

C: Like, a lot of times I would avoid seeing anybody 'cause I was just so pissed off at them all. Now when I see them I'm not pissed off. Before if I did show up, which wasn't very often, I was pissed off, you know. I thought to myself, “Why am I here?” I made sure everybody knew it.

\section{Feelings of Failure and Self-Esteem}

At the beginning of therapy, the client had internalized a strong sense of failure particularly with respect to her family. At the post-therapy change interview she said,

I know now that I'm not stupid, and I'm not a loser. I know that now. But, for years and years and years, if something would go wrong in my life, I would think, "Oh yeah, yeah, I am a loser."

When asked to describe other changes that she had experienced as a result of therapy, the client responded,

I think that was the biggest thing for me because there are certain things now in my life that are different than they were last year. Last year was a year I would love to forget. Things are definitely different this year but there is still some residue from last year and they just don't seem to be bothering me as much. I've taken the importance away from them. I would give things importance that were really not important. I've improved my relationships with certain people and even in my marriage I look at things different. 
Contrasting Two Clients in Emotion-Focused Therapy for Depression 2:

The Case of "Eloise," "It's Like Opening the Windows and Letting the Fresh Air Come In"

R.N. Goldman, J.C. Watson, \& L.S. Greenberg

Pragmatic Case Studies in Psychotherapy, http://pcsp.libraries.rutgers.edu

Volume 7, Module 1, Article 3, pp. 305-338, 06-05-11 [copyright by authors]

\section{Unfinished Business with Father}

At the beginning of therapy the client identified a great deal of resentment and accompanying sadness and hopelessness with respect to her relationship with her father, and had a dominant emotion scheme of feeling unlovable. When asked at the post-therapy change interview if there were specific times in therapy that seemed particularly important or connected to the changes, the client identified chair work as important, as it allowed her to identify and cope with her anger at her parents, particularly her father.

C: I just remember that there was one session that we dealt a lot with my father and that really helped me put things into perspective, you know? And it diffused my anger. It was all of a sudden, instead of being angry at him I felt sorry, not so much sorry for him, but ... more compassion for him.

In the post-therapy session, she agreed with the interviewer that crying in therapy had finally released some of the pent up feelings.

C: It's sad. I think that when you get older you're in your 30 and 40's, 38 like I am now; you think to yourself, all these years wasted. Being angry and not having a relationship and probably never having the kind of relationship. I realize it's just the way my mom and dad are. They're not warm people. They're not. I'm never going to have that real ... so instead of worrying ... more of sadness that it couldn't have been a better home life and stuff. But, you know, I look at it now and say, "Well, that's okay, people have a heck of a lot worse."

\section{Overall Improvement}

Change scores on objective outcome measures across four domains suggest that reliable clinical change occurred. Specifically, pre-post change was measured on four outcome measures: the Beck Depression inventory (BDI); the Global Severity Index (GSI) of the SCL-90; the Inventory of Interpersonal Problems (IIP); and the Rosenberg Self-Esteem Inventory (RSE). For each of these measures, Table 3 lists the clinical cut-off scores on the measure; Eloise's pre, post, and difference scores; and the Reliable Change Index minimum change score to achieve statistical significance (Jacobson \& Truax, 1991). The scores indicate that Eloise moved out of the clinical range on all four outcome indices and that change scores fell below RCI minimum standards on three of four measures, with the fourth (the IIP) being only slightly below the minimum standard. . Thus, change cannot likely be attributed to measurement error (Elliott et al, 2002). Over the course of therapy Eloise showed (a) a striking decrease in depressive symptoms; (b) a decrease in general symptom distress and common psychiatric symptoms; (c) a decrease in distress arising from interpersonal sources; and (d) a striking increase in self-esteem.

\section{Summary}

Eloise entered therapy very depressed. In 11 sessions, she was able to turn herself around. A strong working alliance allowed the therapist and client to work to target, work through and 
The Case of "Eloise," "It's Like Opening the Windows and Letting the Fresh Air Come In"

R.N. Goldman, J.C. Watson, \& L.S. Greenberg

Pragmatic Case Studies in Psychotherapy, http://pcsp.libraries.rutgers.edu

Volume 7, Module 1, Article 3, pp. 305-338, 06-05-11 [copyright by authors]

explore the maladaptive emotions that were propelling her painful, hopeless feelings. Key Emotion-Focused Therapy tasks were used to address specific emotional processing problems. The two-chair task addressed emotional interruption, as well as negative self-evaluation for feelings of failure and low self esteem. The empty chair work addressed unresolved feelings with her father. Overall, Eloise was able to confront fear, access anger, and mourn losses that she experienced. Hopelessness, pain, and anger experienced in the beginning of therapy gave way to underlying sadness. By the end of treatment, she experienced contentment and relief. 
Contrasting Two Clients in Emotion-Focused Therapy for Depression 2:

The Case of "Eloise," "It's Like Opening the Windows and Letting the Fresh Air Come In"

R.N. Goldman, J.C. Watson, \& L.S. Greenberg

Pragmatic Case Studies in Psychotherapy, http://pcsp.libraries.rutgers.edu

Volume 7, Module 1, Article 3, pp. 305-338, 06-05-11 [copyright by authors]

\section{REFERENCES}

Bachman, J., \& O'Malley, P. (1977). Self-esteem in young men: A longitudinal analysis of the impact of educational and occupational attainment. Journal of Personality and Social Psychology, 35, 365-380.

Beck, A.T., Steer, R.A. \& Garbin, M.G. (1988). Psychometric properties of the Beck Depression Inventory: Twenty-five years of evaluation, Clinical Psychology Review, 8, 77-100.

Bordin, E.(1979). The generalizability of the psychoanalytic concept of the working alliance, Psychotherapy: Theory, Research, and Practice, 16, 252-260.

Derogatis, L. R. (1983). SCL-90: Administration, scoring and procedures manual for the revised version. Baltimore: Clinical Psychometric Research.

Derogatis, L. R., Rickels, K., \& Roch, A. F. (1976). The SCL-90 and the MMPI: A step in the validation of a new self-report scale. British Joumal of Psychiatry, 128, 280-289.

Elliott, R.(2002). Hermeneutic Single-Case Efficacy Design, Psychotherapy Research, 12, 1-21.

Elliott, R., Watson, J.C., Goldman, R.N., \& Greenberg, L.S.(2003). Learning emotion-focused therapy: A Process-experiential approach to change. Washington: APA.

Goldman, R.N. (1997). Change in thematic depth of experiencing and outcome in experiential psychotherapy. Unpublished doctoral dissertation, York University, Toronto, Ontario, Canada.

Goldman, R.N., Greenberg, L.S. \& Angus, L. (2006). The effects of adding specific emotionfocused interventions to the therapeutic relationship in the treatment of depression. Psychotherapy Research, 16, 5, 536-546.

Goldman, R.N., Greenberg, L.S. , \& Pos, A. (2005). Depth of emotional experience and outcome, Psychotherapy Research, 15, 248-260.

Greenberg, L.S., Auszra, L, \& Hermann, I.R. (2007). The relationship between emotional productivity, emotional arousal, and outcome in experiential therapy of depression, Psychotherapy Research, 17, 482-493.

Greenberg, L.S.\& Goldman, R.N.(2007). Case Formulation in Emotion-Focused Therapy, in T.D. Eells (Ed.), Handbook of psychotherapy case formulation. New York: Guilford.

Greenberg, L. S., \& Korman, L. (1993). Integrating emotion in psychotherapy integration. Journal of Psychotherapy Integration, 3, 249-266.

Greenberg, L S., \& Malcolm, W. (2002). Resolving unfinished business: Relating process to outcome. Journal of Consulting and Clinical Psychology, 70, 406-416.

Greenberg, L S., Rice, LN., \& Elliott, R. (1993). Facilitating emotional change: The moment-bymoment process. New York: Guilford Press.

Greenberg, L.S. \& Watson, J.C. (2005). Emotion focused therapy for depression. Washington: APA Books.

Greenberg, L. S. \& Watson, J. C. (1998). Experiential therapy of depression: Differential effects of client-centered relationship conditions and process experiential interventions. Psychotherapy-Research, 8(2), 210-224.

Greenberg, L.S. \& Foerster, F.S. (1996). Resolving unfinished business: The process of change. Journal of Consulting and Clinical Psychology, 64, 439-446. 
Contrasting Two Clients in Emotion-Focused Therapy for Depression 2:

The Case of "Eloise," "It's Like Opening the Windows and Letting the Fresh Air Come In"

R.N. Goldman, J.C. Watson, \& L.S. Greenberg

Pragmatic Case Studies in Psychotherapy, http://pcsp.libraries.rutgers.edu

Volume 7, Module 1, Article 3, pp. 305-338, 06-05-11 [copyright by authors]

Greenberg, L.S. \& Malcolm, W. (2002). Resolving unfinished business: Relating process to outcome. Journal of Consulting and Clinical Psychology, 70, 406-416.

Greenberg, L.S. \& Paivio, S.C. (1997). Working with emotions in psychotherapy. New York: Guilford Press.

Greenberg, L. S., Rice, L. N., \& Elliott, R. (1993). Facilitating emotional change: The momentby-moment process. The Guilford Press: New York.

Horowitz, L M., Rosenberg, S. E., Baer, B. A., Ureno, G., \& Villasenor, V. S. (1988). Inventory of interpersonal problems: Psychometric properties and clinical application. Journal of Consulting and Clinical Psychology, 56, 885-892.

Horvath, A.O. (1994). Empirical validation of Bordin's pantheoretical model of the alliance: The Working Alliance Inventory perspective. In A.O. Horvath \& L.S. Greenberg (Ed), The working alliance: Theory, research, and practice, pp. 109-128. Oxford, England: John Wiley \& Sons.

Horvath, A., \& Greenberg, L.S. (1989). Development and Validation of the Working Alliance Inventory, Journal of Counselling Psychology, 36, 2, 223-233.

Jacobson, N.S. \& Truax, P. (1991). Clinical significance: A statistical approach to defining Meaningful change in psychotherapy research, Journal of Consulting and Clinical Psychology, 59, 12-19.

Korman, L. M. (1991). Emotion episodes. Unpublished master’s thesis, York University, Toronto, Ontario, Canada.

Korman, L. M. (1998). Changes in clients' emotion episodes in therapy. Unpublished dissertation, York University, Toronto, Ontario, Canada.

McGough, J., \& \& Curry, J.F. (1992). Utility of the SCL-90-R with depressed and conductdisordered adolescent inpatients. Journal of Personality Assessment, 59,552-563.

Orlinsky, D. (1988). From micro-outcome to mega-outcome: Observational in the measure of outcome, Paper presented at the $19^{\text {th }}$ annual meeting of the Society for Psychotherapy Research, Santa Fe, New Mexico.

Orlinksy, D. \& Howard, K. (1975). Varieties of psychotherapeutic experiences, New York: Teacher's College Press.

Paivio, S.C. \& Greenberg, L.S. (1995). Resolving “unfinished business”: Efficacy of experiential therapy using empty-chair dialogue. Journal of Consulting and Clinical Psychology, 63, 419-425.

Pos, A. E., Greenberg, L. S., Goldman, R., \& Korman, L. (2003). Emotional processing during experiential treatment of depression. Journal of Consulting and Clinical Psychology, 71 (6), 1007-1016.

Rosenberg, M. (1965). Society and the adolescent self-image. Princeton, New Jersey: Princeton University Press.

Schmitz, N., Kruse, J., Heckrath, C., Alberti, L., \& Tress, W. (1999). Diagnosing mental disorders in primary care: The General Health Questionnaire (GHQ) and the Symptom Check List (SCL-90-R) as screening instruments. Social Psychiatry and Psychiatric Epidemiology, 34, 360-366. 
Contrasting Two Clients in Emotion-Focused Therapy for Depression 2:

The Case of "Eloise," "It's Like Opening the Windows and Letting the Fresh Air Come In"

R.N. Goldman, J.C. Watson, \& L.S. Greenberg

Pragmatic Case Studies in Psychotherapy, http://pcsp.libraries.rutgers.edu

Volume 7, Module 1, Article 3, pp. 305-338, 06-05-11 [copyright by authors]

Watson, J.C. \& Bedard, D. (2006). Clients’ emotional processing in psychotherapy: A comparison between cognitive-behavioral and process-experiential psychotherapy. Journal of Consulting and Clinical psychology, 74, 1, 152-159.

Watson, J.C., Goldman, R.N. \& Greenberg, L.S. (2007). Case studies in emotion- focused therapy for depression: Comparing good and bad outcome. Washington: APA Books.

Watson, J. C., Gordon, L.B., Stermac, L., Steckley, P., \& Kalogerakos, F. (2003). Comparing the effectiveness of process-experiential with cognitive-behavioral psychotherapy in the treatment of depression. Journal of Consulting and Clinical Psychology, 71, 773-781.

Watson, J.S., Goldman, R.N., \& Greenberg, L.S. (2011). Contrasting two clients in EmotionFocused Therapy for depression 1: The Case of "Tom," "Trapped in the Tunnel." Pragmatic Case Studies in Psychotherapy, 7(2), Article 3, 268-304. Available: http://hdl.rutgers.edu/1782.1/pcsp_journal 


\section{APPENDIX 1: TRANSCRIPT SEGMENT OF AN EMOTION EPISODE}

Note:

- This emotion episode occurred during an empty-chair exercise within the context of unfinished business with the client's husband.

- $\quad$ A dash (-) = 1-second pause; an exclamation mark (!) before a word = emphasis.

C: yeah, not associating with anybody and I didn't deserve to associate and or I didn't deserve um - - to have friends or that's the pain part, the doubt I missed out

T: yeah

C: that's where the pain comes in. I missed out on so much it's a waste

T: yeah, so this- so tell him about what you missed out on

C: um - - I missed out on being happy. yeah, and just enjoying my children when they were babies um and believing that it was my fault and I have to keep the spirit up. I have to keep on um trying so I- I exhausted myself

T: yeah, so it was exhausting to have to push away all those feelings

C: yeah, um, maybe that was wrong of me to go that way but um that's the only way I knew - - at the time

T: so that's the thing that you were taught in your life

C; yeah

T: was to just keep on trying and making it right

C: that's right. just- just for you because, you know, he's your husband and - you just have to be there for that person no matter what

T: uh-huh, mm-hm

C: what about me, yeah, what about me?

T: so like I'm important too

C: yeah, I count. there's things that, you know, if I want to be happy, I can be happy, instead of having the depression and feeling hopeless everyday 
The Case of "Eloise," "It's Like Opening the Windows and Letting the Fresh Air Come In"

R.N. Goldman, J.C. Watson, \& L.S. Greenberg

Pragmatic Case Studies in Psychotherapy, http://pcsp.libraries.rutgers. edu

Volume 7, Module 1, Article 3, pp. 305-338, 06-05-11 [copyright by authors]

\section{APPENDIX 1 (CONTINUED)}

\section{Five-Component Coding}

- Situation: describing what the client missed out on in her marriage.

- Emotional reaction: pain.

- Action tendency: none mentioned

- Appraisal of situation (I pushed all my needs away for my husband) and self (I did what I knew how to do at the time).

- Need: validation, respect.

\section{List of Emotions Coded Within the EE Measure}

1. pain/hurt

2. sadness

3. hopelessness

4. loneliness

5. anger/resentment

6. contempt/disgust

7. fear/anxiety

8. love

9. joy/excitement

10. contentment/calm/relief

11. shame/guilt

12. pride/self-confidence

13. anger/sadness

14. pride/anger

15. surprise. 
Contrasting Two Clients in Emotion-Focused Therapy for Depression 2:

The Case of "Eloise," "It's Like Opening the Windows and Letting the Fresh Air Come In"

R.N. Goldman, J.C. Watson, \& L.S. Greenberg

Pragmatic Case Studies in Psychotherapy, http://pcsp.libraries.rutgers.edu

Volume 7, Module 1, Article 3, pp. 305-338, 06-05-11 [copyright by authors]

Table 1. Working Alliance Inventory Scores Across Therapy

$\begin{array}{ll}\text { Session } & \text { Score } \\ 1 & 6.25 \\ 2 & 5.58 \\ 3 & 6.42 \\ 4 & 6.58 \\ 5 & 6.50 \\ 6 & 6.83 \\ 7 & 7.00 \\ 8 & 6.92 \\ 9 & 7.00 \\ 10 & 7.00\end{array}$

Table 2. Beck Depression Inventory-Short Form Scores Across Therapy

$\begin{array}{lr}\text { Session } & \text { Score } \\ 1 & 40 \\ 2 & 20 \\ 3 & 12 \\ 4 & 8 \\ 5 & 4 \\ 6 & 2 \\ 7 & 1 \\ 8 & 0 \\ 9 & 0 \\ 10 & 0\end{array}$


Contrasting Two Clients in Emotion-Focused Therapy for Depression 2:

The Case of "Eloise," "It's Like Opening the Windows and Letting the Fresh Air Come In"

R.N. Goldman, J.C. Watson, \& L.S. Greenberg

Pragmatic Case Studies in Psychotherapy, http://pcsp.libraries.rutgers.edu

Volume 7, Module 1, Article 3, pp. 305-338, 06-05-11 [copyright by authors]

Table 3. Outcome Scores

\begin{tabular}{|l|l|l|l|c|l|}
\hline & $\begin{array}{l}\text { Clinical } \\
\text { cut-off } \\
\text { score }\end{array}$ & $\begin{array}{l}\text { Pre- } \\
\text { treatment } \\
\text { score }\end{array}$ & $\begin{array}{l}\text { Post- } \\
\text { treatment } \\
\text { score }\end{array}$ & Difference & $\begin{array}{l}\text { Minimum } \\
\text { RCI\# } \\
\text { change } \\
\text { score } \\
\text { needed to } \\
\text { reach p <.05 }\end{array}$ \\
\hline $\begin{array}{l}\text { Beck Depression } \\
\text { Inventory }\end{array}$ & 17 & 40.00 & $0.00^{*}$ & 40.00 & 10.81 \\
\hline $\begin{array}{l}\text { General Severity } \\
\text { Index of the } \\
\text { SCL-90 }\end{array}$ & .93 & .84 & $.07^{*}$ & .77 & .77 \\
\hline $\begin{array}{l}\text { Inventory of } \\
\text { Interpersonal } \\
\text { Problems }\end{array}$ & 1.5 & .88 & .03 & .85 & .86 \\
\hline $\begin{array}{l}\text { Rosenberg } \\
\text { Self-Esteem } \\
\text { Inventory }\end{array}$ & Not & 13.00 & $36.00^{*}$ & 23.00 & 1.72 \\
\hline
\end{tabular}

\#Note: RCI=Reliable Change Index (Jacobson \& Truax, 1991)

* Statistically significant change, $\mathrm{p}<.05$ 
The Case of "Eloise," "It's Like Opening the Windows and Letting the Fresh Air Come In"

R.N. Goldman, J.C. Watson, \& L.S. Greenberg

Pragmatic Case Studies in Psychotherapy, http://pcsp.libraries.rutgers.edu

Volume 7, Module 1, Article 3, pp. 305-338, 06-05-11 [copyright by authors]

Figure 1. Relative frequency of pain/hurt emotion episodes over course of therapy

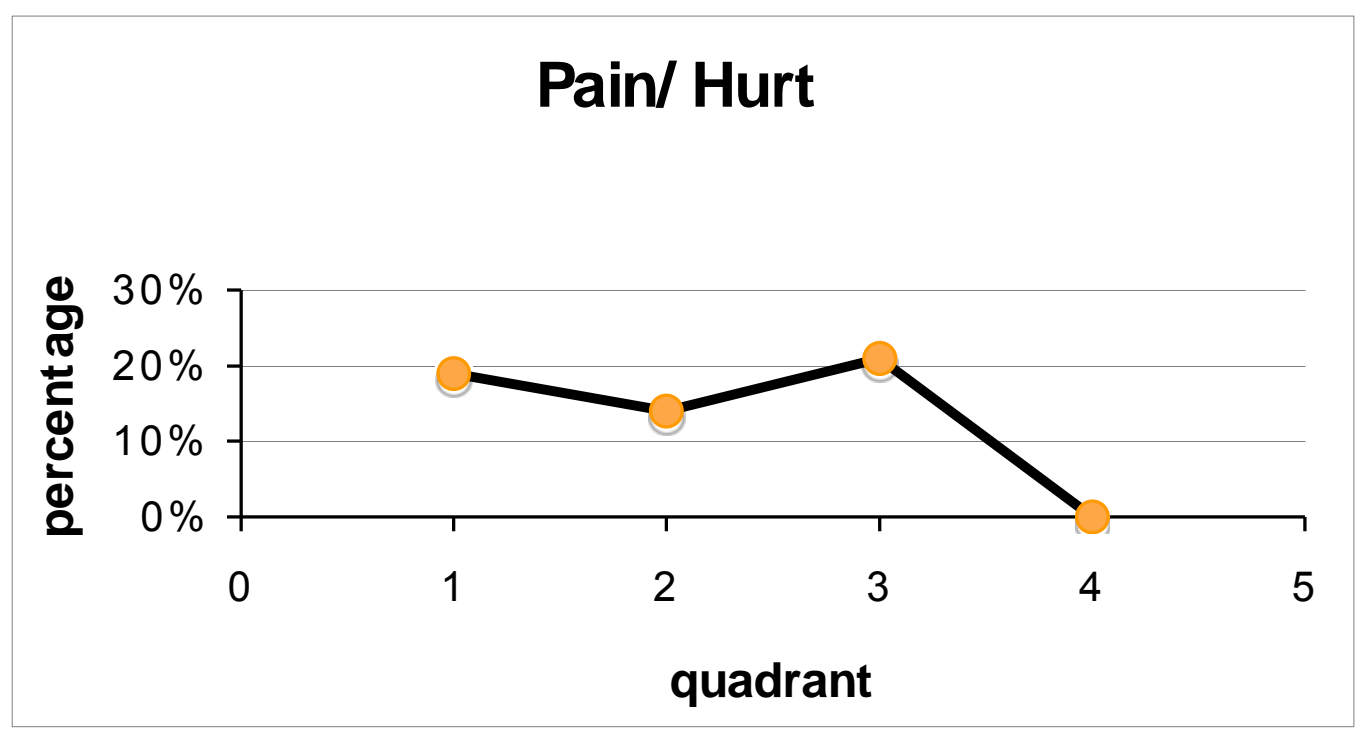

Note: percentage $=$ percentage of overall emotion episodes; quadrant $1=$ sessions 1 -3; quadrant $2=$ sessions 4-6; quadrant 3 = sessions 7 - 8; quadrant 4 = sessions 9-10.

Figure 2. Relative frequency of anger/hurt emotion episodes over course of therapy

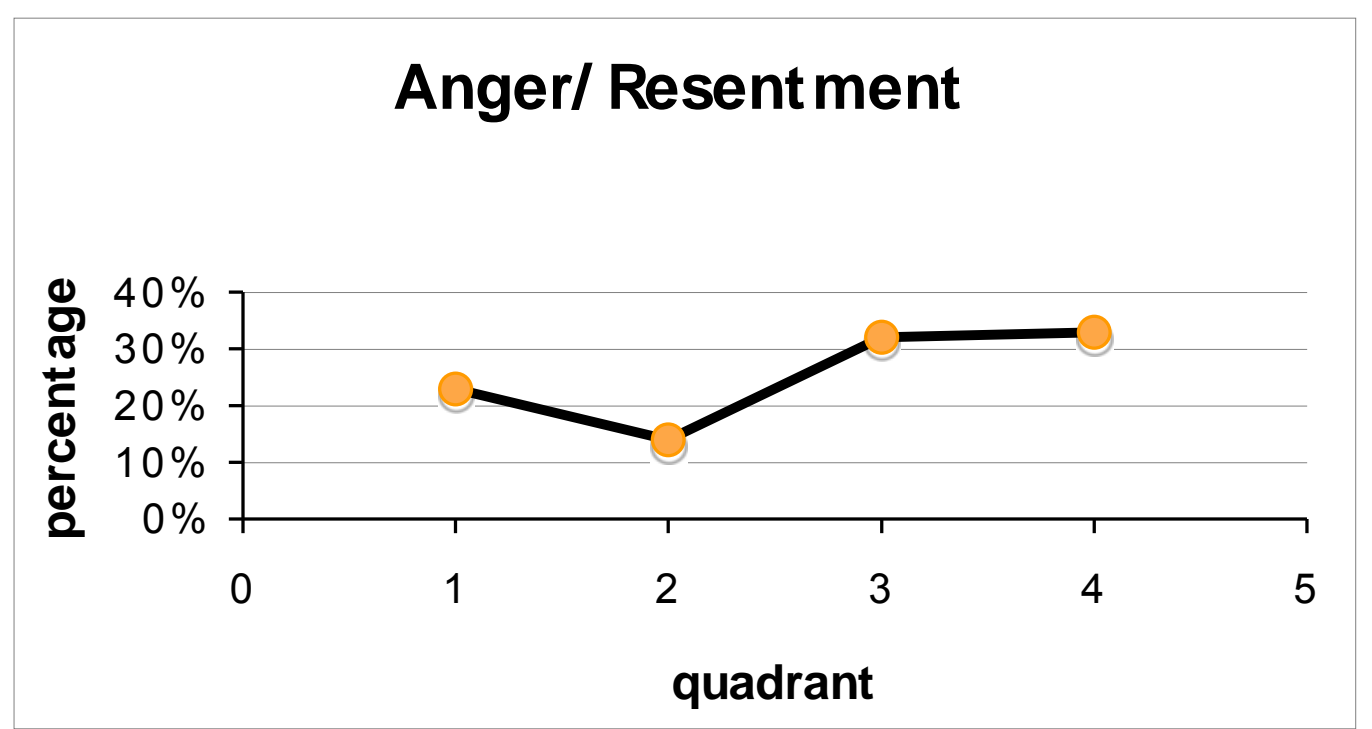

Note: percentage $=$ percentage of overall emotion episodes; quadrant $1=$ sessions 1 -3; quadrant $2=$ sessions 4-6; quadrant 3 = sessions 7 - 8; quadrant 4 = sessions 9-10. 
The Case of "Eloise," "It's Like Opening the Windows and Letting the Fresh Air Come In"

R.N. Goldman, J.C. Watson, \& L.S. Greenberg

Pragmatic Case Studies in Psychotherapy, http://pcsp.libraries.rutgers.edu

Volume 7, Module 1, Article 3, pp. 305-338, 06-05-11 [copyright by authors]

Figure 3. Relative frequency of fear/anxiety emotion episodes over course of therapy

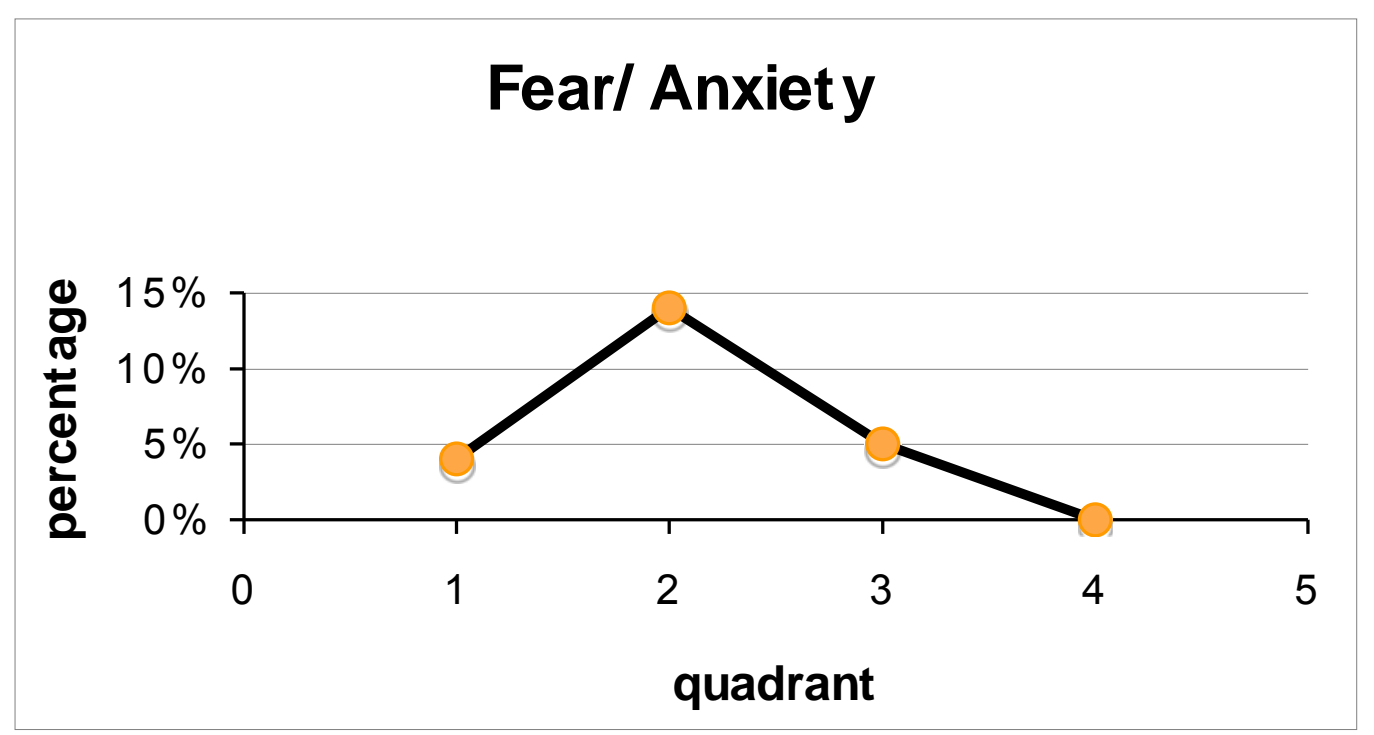

Note: percentage $=$ percentage of overall emotion episodes; quadrant $1=$ sessions 1 -3; quadrant $2=$ sessions 4-6; quadrant 3 = sessions 7 - 8; quadrant 4 = sessions 9-10.

Figure 4. Relative frequency of calm/relief emotion episodes over course of therapy

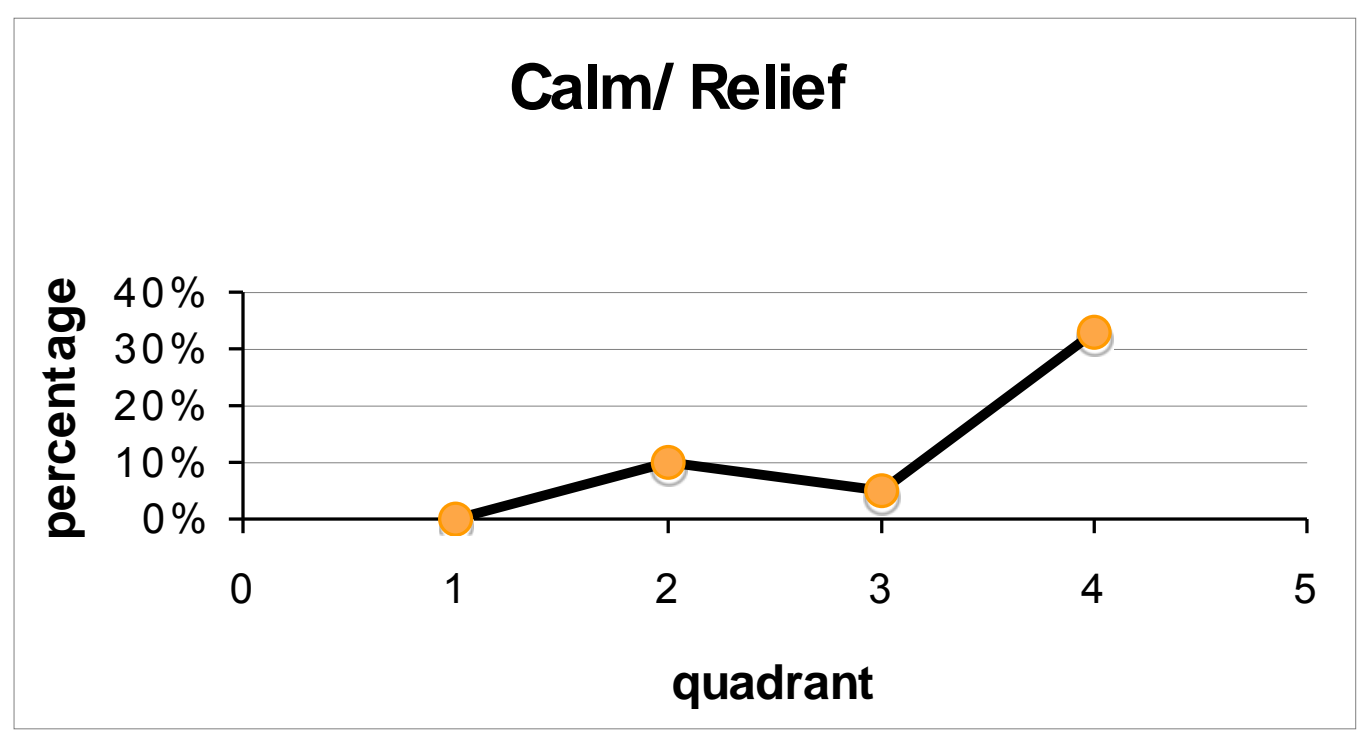

Note: percentage $=$ percentage of overall emotion episodes; quadrant $1=$ sessions 1 -3; quadrant $2=$ sessions 4-6; quadrant 3 = sessions 7 - 8; quadrant 4 = sessions 9-10. 
The Case of "Eloise," "It's Like Opening the Windows and Letting the Fresh Air Come In"

R.N. Goldman, J.C. Watson, \& L.S. Greenberg

Pragmatic Case Studies in Psychotherapy, http://pcsp.libraries.rutgers.edu

Volume 7, Module 1, Article 3, pp. 305-338, 06-05-11 [copyright by authors]

Figure 5. Relative frequency of joy emotion episodes over course of therapy

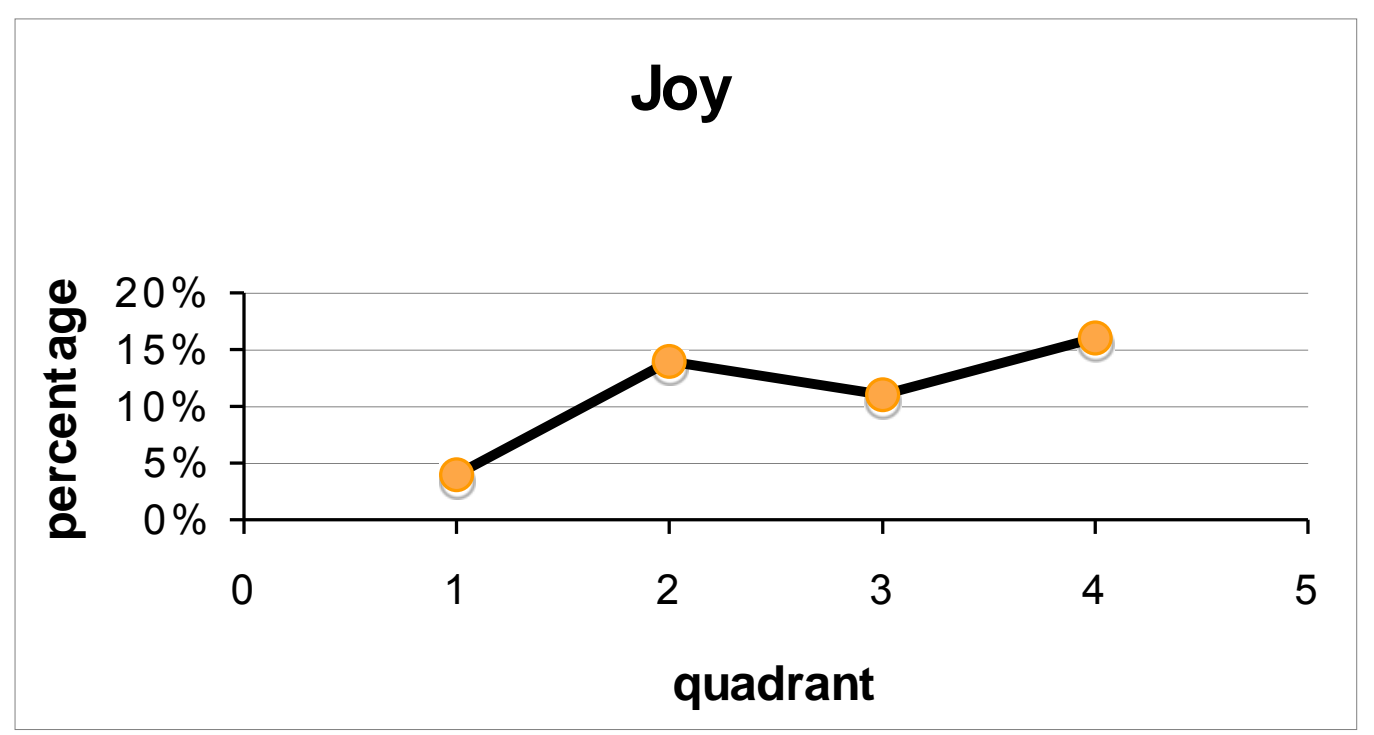

Note: percentage $=$ percentage of overall emotion episodes; quadrant $1=$ sessions 1 -3; quadrant $2=$ sessions 4-6; quadrant 3 = sessions 7 - 8; quadrant 4 = sessions 9-10.

Figure 6. Relative frequency of hopelessness and sadness emotion episodes over course of therapy

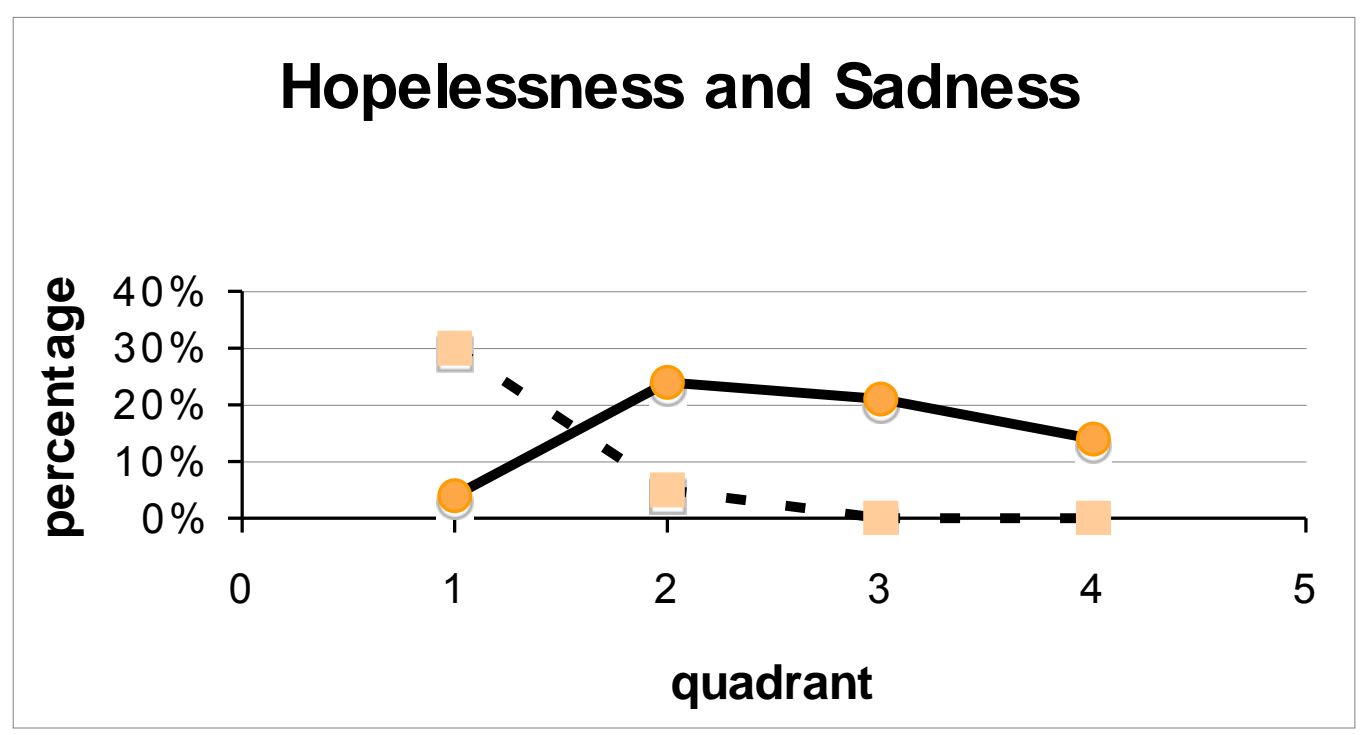

Note: percentage $=$ percentage of overall emotion episodes; quadrant 1 = sessions 1 -3; quadrant 2 = sessions 4-6; quadrant 3 = sessions 7-8; quadrant 4 = sessions 9-10.

Note: Dashed line is hopelessness and the solid line is sadness. 